Arab Univ. J. Agric. Sci., Ain Shams Univ., Cairo, 14(1), 213-234, 2006

\title{
PLANT GROWTH AND NUTRIENTS UPTAKE AS INFLU- ENCED BY APPLICATION OF FARMYARD MANURE AND SOME NATURAL MINERALS TO SANDY SOILS
}

[14]

\author{
Wafaa $^{1}$, M.T. El-Etr ${ }^{1}$; Gehan, H. Youssef ${ }^{1}$ and Laila, K.M. Ali ${ }^{1}$
}

\begin{abstract}
A field experiment was carried out for two seasons 2001 and 2002 at Ismailia Agric. Res. Station to study the comparative effect of farmyard manure (FYM) application, individually or in combination with natural minerals, as sources of micronutrients. Such effect was studied during successive growth stages of wheat (vegetative stage, flowering stage and harvest stage), as well as after maize harvesting, on plant growth, nutrients uptake and wheat - maize productivity. The experiment was designed in a randomized complete block design with three replications. Two levels of FYM (2\% and $3 \%$ ) and three natural minerals, i.e., magnetite (iron oxide, Mag.), basic slag (Bas.) and manganese dust (Md.) at three rates $0.02 \%, 0.05 \%$ and $0.07 \%$, respectively. Obtained results revealed that, at vegetative stage, mineral fertilizers (MF) treatment positively affected the dry matter of both shoots and roots of wheat plants along with contents of nitrogen and potassium in both shoots and roots as well as shoot/root ratios. At flowering stage, obtained data showed that applied farmyard manure at the rate of $3 \%\left(\mathrm{~F}_{2}\right)$ significantly affected the dry matter of both shoots and roots as well as their contents of $\mathrm{N}, \mathrm{P}$ and $\mathrm{K}$. A similar trend was obtained for micronutrients uptake at the two indicated growth stages of wheat, which recorded high values when FYM, at a rate of $3 \%\left(\mathrm{~F}_{2}\right)$, was applied. On the other hand, obtained results indicated that applied FYM at the rate of $2 \%\left(\mathrm{~F}_{1}\right)$ with high rate $(0.07$ $\%$ ) of each of the used natural minerals and FYM at the rate of $3 \%\left(\mathrm{~F}_{2}\right)$ in combination with the moderate rate $(0.05 \%)$ of such minerals recorded high values of all tested parameters. In addition, Basic slag (Bas.), generally, gave the highest values, over control, of dry matter content and macronutrients uptake during the studied two growth stages of wheat, (vegetative and flowering stages). The agronomic yield components of wheat (straw, grains and weight of 1000 grains) were increased when MF was applied; such significant increases were obtained in maize yield (residual effect) as a result of applied FYM individually or combined with natural minerals.
\end{abstract}

Keywords: Farmyard manure (FYM), Natural minerals, Magnetite, Basic slag, Manganese dust, Macronutrients uptake, Micronutrients uptake.

1- Soils, Water and Environment Research Institute, Agricultural Research Center, Giza, Egypt

(Received November 20, 2005)

(Accepted January 14, 2006) 


\section{INTRODUCTION}

Farmyard manure has played an important role in the continuous supply of well-balanced diets of nutrients to crops, and represents an important component of the nutrients cycle in agricultural ecosystems. However, the use of FYM alone may not be enough to meet the enormous nutrient requirements of present-day high yielding cultivars. Thus, integrated nutrient management, in which both organic manures and inorganic fertilizers are used simultaneously, has been suggested as the most effective method to maintain a healthy and sustainable soil system with relatively high crop productivity (Palm $\boldsymbol{e t}$ al 1997).

In a pot experiment, Barssom (1998) reported that 5\% FYM application increased the dry weight of 45 days age plants along with their $\mathrm{N}, \mathrm{P}$ and $\mathrm{K}$ uptake over that of untreated soil. Also, Tolessa and Friesen (2001) added that the growth and yield of maize were increased significantly with the application of FYM enriched with chemical fertilizer. This increase in grain yield reached up to $40 \%$ compared to conventional FYM; such increase in yield may be attributed to the nature and quality of enriched FYM which supplies nutrients in a readily available form to plants; also, such FYM reacts with native soil nutrients in a way that enhance their availability to crops. Moreover, Salib et al (2002) found that application of farmyard manure at a rate of $15 \mathrm{~m}^{3} / \mathrm{fed}$. was preferred for increasing $\mathrm{P}$ uptake by barely straw and $\mathrm{K}$ total content of both grains and straw; each of mineral $\mathrm{P}$ and $\mathrm{K}$ fertilization was, however, preferred for $\mathrm{P}$ total content of grains and whole plants. Heluf (2002) reported an increment of $0.47 \mathrm{t} \mathrm{ha}^{-1}$ in grain yield due to application of FYM during the first year over no FYM, whereas increasing FYM applications from 0 to $20 \mathrm{t} \mathrm{ha}^{-1}$ increased wheat grain yield from 1.97 to $3.31 \mathrm{t} \mathrm{ha}^{-1}$.

Recently, Yang et al (2004) mentioned that both root length density and root weight density of rice plant increased by 30 and $40 \%$ for organic fertilization treatments (chemical fertilizers and wheat straw along with chemical fertilizers and farmyard manure, respectively), as compared with the sole chemical fertilization. However, the effectiveness of FYM combined with micronutrients was previously discussed by Basyouny (2001) who reported that FYM mixed with $\mathrm{Fe}$ and $\mathrm{Zn}$ gave the highest increases in shoot dry weight at the first and second stages of growth and also the highest straw and grain yields of both wheat and maize.

The current work was planned to investigate the individual and interactional effects of farmyard manure and some natural materials on wheat growth stages (vegetative and flowering stages), yield components of wheat- maize crop system (harvest stage), as well as reflection of these applications on nutrients uptake by both wheat and maize plants.

\section{MATERIAL AND METHODS}

Field experiments were carried out at Ismailia Agriculture Research Station during two successive seasons, winter season 2001/2002 with wheat (Triticum aestivum L., cv Giza 168) and summer season 2002 with maize (Zea mays L., cv Giza 10), to study the effect of farmyard manure (FYM) and some natural materials on growth and uptake of nutrients by plants. Some physical and chemical char- 
acteristics of the tested soil samples are shown in (Table, 1).

FYM was applied at two rates $(2 \%$ and $3 \%$ ) individually or combined with micronutrient sources. Used micronutrient sources were magnetic iron oxide (Mag), basic slag (Bas) and manganese dust (Md). They were applied alone at a rate of $0.07 \%(2 \mathrm{~kg} / \mathrm{plot})$ or in combination with FYM levels of $(0.02 \%, 0.05 \%$ and $0.07 \%$ which were equivalent to $0.571,1.432$ and $2 \mathrm{~kg} /$ plot for Mag, Bas and $\mathrm{Md}$, respectively). The analysis of FYM and different micronutrient sources were carried out according to standard methods described by Black (1982); values are shown in Table (2). The treatments were thoroughly mixed with the surface soil layer $(0-15 \mathrm{~cm}$.) of plots, a randomized complete block design with three replications being used, before 15 days from wheat planting (first season). In order to evaluate their residual effect, maize grains was planted on the same plots in summer season. The plot area was $10.5 \mathrm{~m}^{2}$ (3.5 $\mathrm{m}$ long and $3 \mathrm{~m}$ width).

The plots received inorganic fertilizers as follows: ammonium sulfate $(20 \%$ $\mathrm{N})$, superphosphate $\left(15 \% \mathrm{P}_{2} \mathrm{O}_{5}\right)$ and potassium sulfate $\left(48 \% \mathrm{~K}_{2} \mathrm{O}\right)$ at rates of 100,30 and $48 \mathrm{~kg} / \mathrm{fed}$ of $\mathrm{N}, \mathrm{P}_{2} \mathrm{O}_{5}$ and $\mathrm{K}_{2} \mathrm{O}$, respectively.

Mineral fertilizers (MF) were applied at full dose for control treatment; but partially added with other treatments receiving FYM, such inorganic fertilizers were applied to complete the recommended dose for wheat plants. Phosphorus and potassium fertilizers were added before planting, while ammonium sulfate was added in four equal doses after 2, 4, 6 and 8 weeks from planting. The recommended practices of cultivation were carried out till crop maturity. In the second sea- son, maize grains were planted after 15 days from wheat harvesting and received one dose of nitrogen fertilizer at a rate of $20 \mathrm{~kg} / \mathrm{fed} \mathrm{N}$ in the form of ammonium sulfate $(20 \% \mathrm{~N})$.

Table 1. Some physical and chemical characteristics of the experimental soil.

\begin{tabular}{|c|c|}
\hline Soil characteristics & $\begin{array}{l}\text { Val- } \\
\text { ues }\end{array}$ \\
\hline \multicolumn{2}{|l|}{ Particle size distribution $\%$} \\
\hline Coarse Sand & 45.23 \\
\hline Fine sand & 39.53 \\
\hline Silt & 9.24 \\
\hline Clay & 6.00 \\
\hline Texture & Sandy \\
\hline Chemical properties & 2.4 \\
\hline $\mathrm{pH}$ (1:2.5 soil -water suspension) & 7.68 \\
\hline EC dS/m (saturated paste extract) & 0.37 \\
\hline Organic matter $\%$ & 0.52 \\
\hline \multicolumn{2}{|l|}{$\begin{array}{l}\text { Cations and anions in sat. extract } \\
\qquad(\mathrm{meq} / \mathrm{l})\end{array}$} \\
\hline $\mathrm{Ca}^{++}$ & 0.97 \\
\hline $\mathrm{Mg}^{++}$ & 0.87 \\
\hline $\mathrm{Na}^{+}$ & 1.51 \\
\hline $\mathrm{K}^{+}$ & 0.45 \\
\hline $\mathrm{HCO}_{3}^{-}$ & 1.42 \\
\hline $\mathrm{CO}_{3}^{--}$ & - \\
\hline $\mathrm{Cl}^{--}$ & 1.02 \\
\hline $\mathrm{SO}_{4}^{--}$ & 1.36 \\
\hline \multicolumn{2}{|l|}{ Available nutrients (ppm) } \\
\hline $\mathrm{N}$ & 85 \\
\hline $\mathrm{P}$ & 25 \\
\hline K & 125 \\
\hline $\mathrm{Fe}$ & 2.40 \\
\hline Mn & 1.50 \\
\hline $\mathrm{Zn}$ & 0.40 \\
\hline $\mathrm{Cu}$ & 0.20 \\
\hline
\end{tabular}


Table 2. Some characteristics of farmyard manure (FYM) and natural minerals used in the experiment.

\begin{tabular}{|c|c|c|c|c|}
\hline Determination & FYM & $\begin{array}{c}\text { Magnetite } \\
\text { (Mag) }\end{array}$ & $\begin{array}{c}\text { Basic slag } \\
(\mathrm{Bas})\end{array}$ & $\begin{array}{c}\text { Mn dust } \\
(\mathrm{Md})\end{array}$ \\
\hline $\mathrm{EC} \mathrm{dS/m}$ & $3.57 *$ & $0.33 * *$ & $0.39 * *$ & $18.0 * *$ \\
\hline PH & $7.85^{*}$ & $7.8 * *$ & $10.70 * *$ & $7.23 * *$ \\
\hline $\mathrm{C} / \mathrm{N}$ ratio & $16: 1$ & - & - & - \\
\hline \multicolumn{5}{|c|}{ Available nutrients (ppm) } \\
\hline $\mathrm{N}$ & 9800 & 166 & 127 & 208 \\
\hline $\mathrm{P}$ & 600 & 8.40 & 12.4 & 6.73 \\
\hline $\mathrm{K}$ & 21900 & 146 & 133 & 287 \\
\hline $\mathrm{Fe}$ & 66.6 & 22.0 & 18.2 & 1.92 \\
\hline $\mathrm{Mn}$ & 85.4 & 7.48 & 231 & 3.23 \\
\hline $\mathrm{Zn}$ & 13.9 & 2.70 & 3.65 & 12.5 \\
\hline $\mathrm{Cu}$ & 8.84 & 0.43 & 0.06 & 8.41 \\
\hline
\end{tabular}

Plant samples were taken from each plot at two growth stages (vegetative and flowering stages), other samples being taken at harvested stage for both wheat and maize plants. After maturity, wheat and maize plants were harvested and the yield components (grains, straw and weight of 1000 grain) of each plot were recoded. Plant samples of wheat and maize were collected from bulk plot, weighed, oven dried at $70 \mathrm{C}^{\mathrm{o}}$, ground and prepared for digestion using $\mathrm{H}_{2} \mathrm{SO}_{4}$ and $\mathrm{H}_{2} \mathrm{O}_{2}$ method described by Black (1982). The digests were then subjected to measurement for macronutrients ( $\mathrm{N}, \mathrm{P}$ and $\mathrm{K}$ ) using procedures described by Chapman and Pratt (1961).

Obtained results were subjected to statistical analysis according to Snedecor and Cochran (1980) and the treatments were compared by using L.S.D. at 0.05 level of probability. Expression of "total content" has been adopted, for both shoots and grains, to be equivalent to "uptake" used for roots.

\section{RESULTS AND DISCUSSION}

\section{I- Growth of wheat and maize under tested treatments}

\section{1- Response of wheat growth stages to applied FYM and natural minerals}

As shown in Table (3), dry matter yield of shoots and roots as well as shoot/root ratio, at vegetative stage, were significantly superior with application of mineral fertilizer (MF) for both shoots and roots; added (Bas), alone, at a rate of 0.07 was highly significant for shoot/root ratio. Relatively different trend was obtained at flowering stage whose values appeared to be significant with applied 
Table 3. Dry matter of both shoots and roots (g/plant) along with shoot/root ratios of wheat plants at two growth stages as affected by applied FYM and natural minerals treatments.

\begin{tabular}{|c|c|c|c|c|c|c|c|c|}
\hline \multicolumn{2}{|c|}{ Natural minerals } & \multirow{2}{*}{$\begin{array}{l}\text { FYM } \\
\text { levels }\end{array}$} & \multicolumn{3}{|c|}{ Vegetative stage } & \multicolumn{3}{|c|}{ Flowering stage } \\
\hline Forms & $\begin{array}{c}\text { Rates } \\
(\%)\end{array}$ & & Shoots & Roots & $\begin{array}{c}\text { Shoot/root } \\
\text { ratios } \\
\end{array}$ & Shoots & Roots & $\begin{array}{c}\text { Shoot/root } \\
\text { ratios }\end{array}$ \\
\hline \multicolumn{2}{|c|}{ Control } & \multirow{4}{*}{$0 \%$} & 5.48 & 2.50 & 2.19 & 10.5 & 4.00 & 2.63 \\
\hline Mag & & & 2.59 & 1.06 & 2.44 & 9.21 & 2.51 & 3.68 \\
\hline Bas & 0.07 & & 3.01 & 1.29 & 3.14 & 8.69 & 3.02 & 2.88 \\
\hline $\mathrm{Md}$ & & & 3.31 & 1.07 & 2.79 & 8.23 & 1.26 & 6.53 \\
\hline \multicolumn{2}{|c|}{$\mathrm{FYM}\left(\mathrm{F}_{1}\right)$} & & 3.54 & 1.66 & 2.13 & 9.48 & 2.80 & 3.38 \\
\hline \multirow[t]{3}{*}{ Mag } & 0.02 & & 3.11 & 1.81 & 1.72 & 9.71 & 1.44 & 6.74 \\
\hline & 0.05 & & 4.21 & 2.40 & 1.75 & 11.6 & 1.26 & 9.21 \\
\hline & 0.07 & & 4.68 & 2.44 & 2.19 & 11.7 & 2.97 & 3.94 \\
\hline \multirow[t]{3}{*}{ Bas } & 0.02 & & 4.10 & 1.50 & 2.73 & 9.39 & 1.95 & 4.82 \\
\hline & 0.05 & $2 \%$ & 4.57 & 2.00 & 2.29 & 11.0 & 2.86 & 3.84 \\
\hline & 0.07 & & 5.05 & 2.35 & 2.15 & 15.9 & 3.24 & 4.91 \\
\hline \multirow[t]{3}{*}{$\mathrm{Md}$} & 0.02 & & 3.71 & 2.22 & 1.67 & 11.7 & 1.27 & 9.21 \\
\hline & 0.05 & & 3.90 & 2.08 & 1.88 & 11.5 & 1.63 & 7.06 \\
\hline & 0.07 & & 4.57 & 2.28 & 2.00 & 14.2 & 2.33 & 6.09 \\
\hline \multicolumn{2}{|c|}{$\mathrm{FYM}\left(\mathrm{F}_{2}\right)$} & & 3.67 & 2.21 & 1.66 & 11.4 & 3.23 & 3.53 \\
\hline \multirow[t]{3}{*}{ Mag } & 0.02 & & 4.70 & 1.95 & 2.41 & 13.7 & 3.24 & 4.23 \\
\hline & 0.05 & & 5.01 & 2.49 & 2.01 & 16.3 & 3.81 & 4.28 \\
\hline & 0.07 & & 4.02 & 1.70 & 2.36 & 12.0 & 3.14 & 3.82 \\
\hline \multirow[t]{3}{*}{ Bas } & 0.02 & & 4.43 & 2.08 & 2.13 & 18.3 & 3.83 & 4.78 \\
\hline & 0.05 & $3 \%$ & 4.70 & 3.07 & 1.53 & 18.9 & 4.38 & 4.32 \\
\hline & 0.07 & & 4.26 & 2.04 & 2.09 & 14.7 & 3.43 & 4.29 \\
\hline \multirow[t]{3}{*}{$\mathrm{Md}$} & 0.02 & & 3.96 & 2.26 & 1.75 & 10.2 & 4.04 & 2.52 \\
\hline & 0.05 & & 4.05 & 2.36 & 1.72 & 13.2 & 4.24 & 3.11 \\
\hline & 0.07 & & 3.53 & 1.55 & 2.28 & 9.89 & 3.11 & 3.18 \\
\hline \multicolumn{2}{|c|}{ L.S.D. $5 \%$} & & 0.43 & 0.19 & 0.02 & 0.005 & 0.005 & 0.02 \\
\hline
\end{tabular}

FYM $3 \%\left(\mathrm{~F}_{2}\right)$ combined with moderate rate of basic slag (Bas, $0.05 \%$ ) either for shoots or roots, both Mag at a rate $0.05 \%$ and $\mathrm{Md}$ at rate of $0.02 \%$ combined with
FYM $\left(\mathrm{F}_{1}\right)$ being superior for shoot/root ratio. These variations may be due to the presence of available nutrients especially at vegetative stage as a result of added 
mineral fertilizers. Also, at flowering stage, decomposition of FYM led to released available nutrients which should be reflected on dry matter for shoots and roots at this stage.

Generally, application for each of Mag, Bas and Md alone was inferior, regarding the effect on dry matter of both shoots and roots, as compared to combinations with FYM or control (MF) at the two studied growth stages; such effect agrees with the results reported by Basyouny (2001) who found that FYM mixed with $\mathrm{Fe}$ and $\mathrm{Zn}$ gave the highest increases in shoots dry weight during vegetative and flowering stages of wheat.

Effect of FYM was clear when FYM $\left(\mathrm{F}_{1}\right)$ was applied with high rates $(0.07 \%)$ of each of the used natural minerals. Also, application of FYM with a rate $3 \%$ $\left(\mathrm{F}_{2}\right)$, however, recorded high values of shoots and roots when mixed with moderate rates $(0.05 \%)$ of different sources of minerals at vegetative and flowering stages. On the other hand, shoot/root ratios did not show any obvious trend at both growth stages.

From the above mentioned data, it can be noticed that, regardless of applied natural mineral rates, applied basic slag (Bas) in combination with different rates of FYM, generally, gave the highest values over control for dry matter content of shoots and roots along with shoot/root ratios during the two studied growth stages.

\section{2- Yield components of both wheat- maize crop systems}

Data shown in Table (4) reveal that, values of wheat yield components (straw, grains and weight of 1000 grain) were significantly more stimulated with appli- cation of mineral fertilizer (MF) as compared to applied FYM either alone or in combination with natural minerals. These results are in agreement with those of Salib et al (2002) who reported that applied FYM alone was not significantly superior to the control treatment for barley grain and straw yields and 1000 grain weight. Opposite trend was obtained by maize yields (residual effect), effect appeared to be significant with applied FYM $\left(\mathrm{F}_{2}\right)$ combined with $\mathrm{Md}$ at a rate of $0.05 \%$.

Regarding the application of natural minerals alone at a rate of $0.07 \%$, there was no general effect on wheat and maize yield as compared to their combination with either FYM or mineral fertilizer $(\mathrm{MF})$; manganese dust $(\mathrm{Md})$ at a rate of $0.07 \%$, as compared to other sources of natural minerals, tended to increase both of wheat and maize yields.

Responses of wheat- maize yield components (grains, straw and weight of 1000 grain) to rate of mineral application seemed to be, generally, most favoured with presence of FYM $\left(\mathrm{F}_{1}\right)$ accompanied with high rates $(0.07 \%)$ of all natural minerals and FYM $\left(\mathrm{F}_{2}\right)$ accompanied with moderate rates $(0.05 \%)$ of such minerals.

With respect to the effect of natural minerals forms, results show that wheat yield (first season) and maize yield (residual effect) were generally superior when using manganese dust (Md) at a rate of $0.07 \%$ and $0.05 \%$ combined with FYM $2 \%\left(\mathrm{~F}_{1}\right)$ and FYM $3 \%\left(\mathrm{~F}_{2}\right)$, respectively. This is true, in spite of high values of wheat yield recorded when Mag $(0.05 \%)$ combined with FYM $3 \%\left(\mathrm{~F}_{2}\right)$ was applied. These data agreed with the results reported by Basyouny (2001) who found that the FYM mixed with $\mathrm{Fe}$ and 
Table 4. Responses of wheat and maize yields to applied farmyard manure and natural mineral treatments

\begin{tabular}{|c|c|c|c|c|c|c|c|c|}
\hline \multicolumn{2}{|c|}{ Natural minerals } & \multirow{2}{*}{$\begin{array}{l}\text { FYM } \\
\text { levels }\end{array}$} & \multicolumn{2}{|c|}{ Grain } & \multicolumn{2}{|c|}{ Straw } & \multicolumn{2}{|c|}{$\begin{array}{c}\text { Weight of } 1000 \\
\text { grain }\end{array}$} \\
\hline Forms & $\begin{array}{c}\text { Rates } \\
(\%)\end{array}$ & & $\begin{array}{c}\text { Yield } \\
\text { Kg/fed. }\end{array}$ & (R.P.)* & $\begin{array}{c}\text { Yield } \\
\text { Ton/fed }\end{array}$ & (R.P.)* & Gram & (R.P.)* \\
\hline \multicolumn{9}{|c|}{ A- First season (wheat) } \\
\hline & Control & & 2133 & - & 5.39 & - & 48.0 & - \\
\hline Mag & & & 1250 & 58.6 & 2.25 & 41.7 & 40.5 & 84.4 \\
\hline Bas & 0.07 & $0 \%$ & 1245 & 58.4 & 2.12 & 39.3 & 39.9 & 83.1 \\
\hline Md & & & 1258 & 59.0 & 2.35 & 43.6 & 41.9 & 87.3 \\
\hline \multicolumn{2}{|c|}{ FYM (F1) } & & 1041 & - & 2.11 & - & 42.6 & - \\
\hline \multirow{3}{*}{ Mag } & 0.02 & & 1766 & 169.6 & 3.18 & 150.7 & 41.2 & 96.7 \\
\hline & 0.05 & & 1880 & 180.6 & 3.67 & 173.9 & 41.2 & 96.7 \\
\hline & 0.07 & & 1966 & 188.9 & 3.77 & 178.7 & 42.2 & 99.1 \\
\hline \multirow{3}{*}{ Bas } & 0.02 & & 1377 & 132.3 & 2.91 & 137.9 & 39.8 & 93.4 \\
\hline & 0.05 & $2 \%$ & 1688 & 162.2 & 2.89 & 137.0 & 40.1 & 94.1 \\
\hline & 0.07 & & 1958 & 188.1 & 3.78 & 179.1 & 41.0 & 96.2 \\
\hline \multirow{3}{*}{$\mathrm{Md}$} & 0.02 & & 1899 & 182.4 & 3.23 & 153.1 & 39.4 & 92.5 \\
\hline & 0.05 & & 2027 & 194.7 & 4.00 & 189.6 & 41.3 & 96.9 \\
\hline & 0.07 & & 2078 & 199.6 & 4.18 & 198.1 & 42.2 & 99.1 \\
\hline \multicolumn{2}{|c|}{ FYM (F2) } & & 1247 & - & 2.43 & - & 44.0 & - \\
\hline \multirow{3}{*}{ Mag } & 0.02 & & 1549 & 124.2 & 2.88 & 118.5 & 42.2 & 95.9 \\
\hline & 0.05 & & 1654 & 132.6 & 3.36 & 138.3 & 43.3 & 98.4 \\
\hline & 0.07 & & 1272 & 102.0 & 2.34 & 96.3 & 42.1 & 95.7 \\
\hline \multirow{3}{*}{ Bas } & 0.02 & & 1556 & 124.8 & 2.94 & 121.0 & 43.2 & 98.2 \\
\hline & 0.05 & $3 \%$ & 1585 & 127.1 & 3.11 & 128.0 & 44.4 & 100.9 \\
\hline & 0.07 & & 1377 & 110.4 & 2.64 & 108.6 & 40.8 & 92.7 \\
\hline \multirow{3}{*}{ Md } & 0.02 & & 1490 & 119.5 & 2.81 & 115.6 & 42.5 & 96.6 \\
\hline & 0.05 & & 1511 & 121.2 & 2.95 & 121.4 & 43.1 & 98.0 \\
\hline & 0.07 & & 1415 & 113.5 & 2.69 & 110.7 & 42.0 & 95.5 \\
\hline \multicolumn{2}{|c|}{ L.S.D. $5 \%$} & & 14.2 & - & 0.02 & - & 1.02 & - \\
\hline
\end{tabular}

Arab Univ. J. Agric. Sci., 14(1), 2006 
Table 4. Cont.

\begin{tabular}{|c|c|c|c|c|c|c|c|c|}
\hline \multicolumn{2}{|c|}{ Natural minerals } & \multirow{2}{*}{$\begin{array}{l}\text { FYM } \\
\text { levels }\end{array}$} & \multicolumn{2}{|c|}{ Grain } & \multicolumn{2}{|c|}{ Straw } & \multicolumn{2}{|c|}{$\begin{array}{c}\text { Weight of } 1000 \\
\text { grain }\end{array}$} \\
\hline Forms & $\begin{array}{c}\text { Rates } \\
(\%)\end{array}$ & & $\begin{array}{c}\text { Yield } \\
\mathrm{Kg} / \text { fed. }\end{array}$ & (R.P.)* & $\begin{array}{c}\text { Yield } \\
\text { Ton/fed }\end{array}$ & (R.P.)* & Gram & (R.P.)* \\
\hline \multicolumn{9}{|c|}{ B- Second season (maize) } \\
\hline & Control & & 1563 & - & 3.40 & - & 354 & - \\
\hline Mag & & & 1120 & 71.7 & 2.10 & 61.8 & 349 & 98.6 \\
\hline Bas & 0.07 & $0 \%$ & 1157 & 74.0 & 2.31 & 67.9 & 372 & 105.1 \\
\hline \multirow[t]{3}{*}{ Md } & & & 1200 & 76.8 & 2.54 & 74.7 & 377 & 106.5 \\
\hline & FYM (F1) & & 2693 & - & 2.32 & - & 326 & - \\
\hline & 0.02 & & 2650 & 98.4 & 3.02 & 130.2 & 311 & 95.4 \\
\hline \multirow[t]{3}{*}{ Mag } & 0.05 & & 3023 & 112.3 & 3.82 & 164.7 & 373 & 114.4 \\
\hline & 0.07 & & 3280 & 121.8 & 4.03 & 173.7 & 375 & 115.0 \\
\hline & 0.02 & & 2553 & 94.8 & 2.92 & 125.9 & 323 & 99.1 \\
\hline \multirow[t]{3}{*}{ Bas } & 0.05 & $2 \%$ & 3300 & 122.5 & 3.28 & 141.4 & 339 & 104.0 \\
\hline & 0.07 & & 3700 & 137.4 & 3.53 & 152.2 & 384 & 117.8 \\
\hline & 0.02 & & 2737 & 101.6 & 2.54 & 109.5 & 368 & 112.9 \\
\hline \multirow[t]{4}{*}{$\mathrm{Md}$} & 0.05 & & 3184 & 118.2 & 2.78 & 119.8 & 378 & 116.0 \\
\hline & 0.07 & & 3301 & 122.6 & 4.24 & 182.8 & 393 & 120.6 \\
\hline & FYM (F2) & & 3250 & - & 3.8 & - & 376 & - \\
\hline & 0.02 & & 2997 & 92.2 & 3.83 & 100.8 & 347 & 92.3 \\
\hline \multirow[t]{3}{*}{ Mag } & 0.05 & & 3070 & 94.5 & 3.83 & 100.8 & 376 & 100.0 \\
\hline & 0.07 & & 3600 & 110.8 & 3.72 & 97.9 & 321 & 85.4 \\
\hline & 0.02 & & 3810 & 117.2 & 2.84 & 74.7 & 385 & 102.4 \\
\hline \multirow[t]{3}{*}{ Bas } & 0.05 & $3 \%$ & 3985 & 122.6 & 4.12 & 108.4 & 387 & 102.9 \\
\hline & 0.07 & & 3163 & 97.3 & 2.73 & 71.8 & 341 & 90.7 \\
\hline & 0.02 & & 3290 & 101.2 & 3.65 & 96.1 & 374 & 99.5 \\
\hline \multirow[t]{2}{*}{$\mathrm{Md}$} & 0.05 & & 3863 & 118.9 & 4.72 & 124.2 & 433 & 115.2 \\
\hline & 0.07 & & 2487 & 76.5 & 3.12 & 82.1 & 336 & 89.4 \\
\hline \multicolumn{2}{|c|}{ L.S.D. 5\% } & & 23.5 & - & 0.02 & - & 2.15 & - \\
\hline
\end{tabular}

* Relative percent (R.P. $)=($ Treatment $/$ Control $)$ X 100 
$\mathrm{Zn}$ gave the highest yields of straw and grains of wheat and maize. These data was explained by Zaharieva and Abadia (1998) on the basis of the role of iron in the formation of chlorophyll molecule, which leads to a high growth of green parts then followed by high production of seeds.

II- Nutrients uptake by plants as affected by tested treatments

\section{A- Macronutrients uptake by wheat during the studied growth stag- es}

Table (5) shows data representing the $\mathrm{N}, \mathrm{P}$ and $\mathrm{K}$ total contents of shoots and roots along with shoot/root ratios of the studied wheat plants at vegetative and flowering stages. At vegetative stage, results show that the values of nitrogen and potassium were generally significantly favoured in plants receiving mineral fertilizer (MF) as compared to applied FYM alone. This is true, in spite of superiority of phosphorus total content of shoots and roots when FYM $3 \%\left(\mathrm{~F}_{2}\right)$ was applied. Obtained results may be due to the maintenance for fertilizer $\mathrm{P}$ in biological forms by supplying fertilizer $\mathrm{P}$ in combination with farmyard manure which promote the cycling of $\mathrm{P}$ through the soil microbial biomass and associated metabolite pools, with the expected result of decreasing $\mathrm{P}$ fixation and increased plant availability and consequently improved status of such element in plants. (Ayaga et al 2006).

At flowering stage, relatively different trend was obtained; values of nutrients total contents in shoots along with shoot/root ratios appeared to be significantly affected with applied high rate of
FYM $3 \%\left(\mathrm{~F}_{2}\right)$, mineral fertilizer (MF) being superior for roots. This agrees with results reported by Negm et al (2002) who indicated that both of FYM $\left(15 \mathrm{~m}^{3}\right.$ and $30 \mathrm{~m}^{3}$ per fed.) were significantly effective in increasing absorbed macro elements by different parts of maize plants.

With regard to applied natural minerals alone at a rate of $0.07 \%$, indicated results reveal that manganese dust $(\mathrm{Md})$ generally gave the highest values of nutrients total contents $(\mathrm{N}, \mathrm{P}$ and $\mathrm{K})$ by shoots and roots during the vegetative stage, basic slag (Bas) being superior for shoot/root ratios. An opposite trend was encountered during the flowering stage, whose values of nutrients uptake were superior for shoots and roots when Bas. was applied, superiority for shoot/root ratios being encountered when manganese dust (Md) was applied.

Generally, obtained results showed that applied FYM $2 \%\left(\mathrm{~F}_{1}\right)$ in combination with high rate of natural mineral 0.07 $\%$ as well as applied FYM $3 \%\left(\mathrm{~F}_{2}\right)$ with moderate rate $0.05 \%$ was favourable for NPK uptake for both shoots and roots at the two studied growth stages of wheat.

Comparing the effects of natural mineral forms, at the rate of $0.07 \%$ and $0.05 \%$ combined with FYM $\left(\mathrm{F}_{1}\right)$ and FYM 3\% $\left(\mathrm{F}_{2}\right)$, respectively, data show that, at vegetative stage, no clear trend was observed for NPK uptake by either shoots or roots of wheat plant. At flowering stage, Bas was superior for NPK uptake by indicated wheat plant parts.

\section{B- Macronutrients uptake at har- vest stage of wheat-maize system}

With respect to nutrients uptake of both wheat (first season) and maize 
Table 5. Macronutrients total contents of (mg/plant) of both shoots $(\mathrm{S})$ and roots $(\mathrm{R})$ along with shoot / root ratios (S/R) of wheat plants as effected by applied FYM and natural mineral treatments at both vegetative and flowering stages of growth.

\begin{tabular}{|c|c|c|c|c|c|c|c|c|c|c|c|}
\hline \multicolumn{2}{|c|}{ Natural minerals } & \multirow{2}{*}{$\begin{array}{l}\text { FYM } \\
\text { levels }\end{array}$} & \multicolumn{3}{|c|}{$\mathrm{N}$} & \multicolumn{3}{|c|}{$\mathrm{P}$} & \multicolumn{3}{|c|}{$\mathrm{K}$} \\
\hline Forms & $\begin{array}{l}\text { Rates } \\
(\%)\end{array}$ & & $S$ & $\mathrm{R}$ & $\mathrm{S} / \mathrm{R}$ & $S$ & $\mathrm{R}$ & $\mathrm{S} / \mathrm{R}$ & $S$ & $\mathrm{R}$ & $\mathrm{S} / \mathrm{R}$ \\
\hline \multicolumn{12}{|c|}{ A- Vegetative stage } \\
\hline \multicolumn{2}{|c|}{ Control } & & 236 & 68.5 & 3.45 & 14.0 & 4.5 & 3.11 & 257 & 67.3 & 3.82 \\
\hline \multicolumn{2}{|l|}{ Mag } & & 118 & 26.5 & 4.34 & 8.52 & 6.67 & 1.28 & 123 & 23.4 & 5.26 \\
\hline Bas & 0.07 & $0 \%$ & 123 & 22.6 & 5.44 & 7.82 & 4.70 & 1.67 & 149 & 25.3 & 5.89 \\
\hline \multicolumn{2}{|l|}{ Md } & & 135 & 29.6 & 4.56 & 8.61 & 5.99 & 1.44 & 151 & 32.7 & 4.62 \\
\hline \multicolumn{2}{|c|}{ FYM (F1) } & & 147 & 42.8 & 3.43 & 13.8 & 3.82 & 3.61 & 158 & 53.7 & 2.94 \\
\hline \multirow[t]{3}{*}{ Mag } & 0.02 & & 122 & 46.3 & 2.63 & 11.8 & 4.8 & 2.46 & 131 & 52.5 & 2.50 \\
\hline & 0.05 & & 173 & 56.2 & 3.08 & 14.9 & 9.27 & 1.61 & 132 & 60.9 & 2.17 \\
\hline & 0.07 & & 197 & 61.2 & 3.77 & 22.1 & 11.6 & 1.91 & 162 & 69.8 & 2.32 \\
\hline \multirow[t]{3}{*}{ Bas } & 0.02 & & 151 & 32.3 & 4.67 & 16.8 & 5.7 & 2.95 & 139 & 39.0 & 3.56 \\
\hline & 0.05 & $2 \%$ & 176 & 45.2 & 3.89 & 17.8 & 7.6 & 2.34 & 187 & 44.2 & 4.23 \\
\hline & 0.07 & & 196 & 61.3 & 3.20 & 19.7 & 8.69 & 2.73 & 221 & 56.2 & 3.93 \\
\hline \multirow[t]{3}{*}{$\mathrm{Md}$} & 0.02 & & 125 & 59.1 & 2.12 & 15.2 & 9.10 & 1.67 & 129 & 53.5 & 2.41 \\
\hline & 0.05 & & 149 & 52.8 & 2.82 & 15.2 & 8.11 & 1.87 & 161 & 58.1 & 2.77 \\
\hline & 0.07 & & 206 & 66.6 & 3.09 & 16.5 & 10.9 & 1.51 & 196 & 67.2 & 2.92 \\
\hline \multicolumn{2}{|c|}{ FYM (F2) } & & 151 & 48.4 & 3.12 & 14.3 & 8.39 & 1.70 & 145 & 56.6 & 2.56 \\
\hline \multirow[t]{3}{*}{ Mag } & 0.02 & & 185 & 50.3 & 3.68 & 16.5 & 7.48 & 2.21 & 211 & 61.0 & 3.46 \\
\hline & 0.05 & & 232 & 60.5 & 3.83 & 17.5 & 10.2 & 1.72 & 234 & 64.6 & 3.62 \\
\hline & 0.07 & & 195 & 43.9 & 4.44 & 14.1 & 6.04 & 2.33 & 207 & 57.0 & 3.63 \\
\hline \multirow[t]{3}{*}{ Bas } & 0.02 & & 169 & 55.1 & 3.07 & 17.7 & 9.79 & 1.81 & 216 & 65.7 & 3.27 \\
\hline & 0.05 & $3 \%$ & 172 & 58.0 & 2.97 & 23.7 & 14.4 & 1.37 & 239 & 83.2 & 2.87 \\
\hline & 0.07 & & 167 & 55.0 & 3.04 & 17.0 & 9.56 & 1.78 & 186 & 82.9 & 2.24 \\
\hline \multirow[t]{3}{*}{$\mathrm{Md}$} & 0.02 & & 173 & 51.3 & 3.37 & 11.5 & 8.14 & 1.41 & 204 & 59.4 & 3.43 \\
\hline & 0.05 & & 187 & 56.4 & 3.32 & 21.9 & 12.0 & 1.83 & 228 & 61.1 & 3.73 \\
\hline & 0.07 & & 160 & 39.9 & 4.01 & 12.4 & 7.29 & 1.70 & 173 & 54.6 & 3.17 \\
\hline \multicolumn{2}{|c|}{ L.S.D. $5 \%$} & & 19.5 & 0.02 & 0.02 & 0.02 & 0.02 & 0.02 & 0.33 & 0.02 & 0.02 \\
\hline
\end{tabular}


Table 5. Cont.

\begin{tabular}{|c|c|c|c|c|c|c|c|c|c|c|c|}
\hline \multicolumn{2}{|c|}{ Natural minerals } & \multirow{2}{*}{$\begin{array}{l}\text { FYM } \\
\text { levels }\end{array}$} & \multicolumn{3}{|c|}{$\mathrm{N}$} & \multicolumn{3}{|c|}{$\mathrm{P}$} & \multicolumn{3}{|c|}{ K } \\
\hline Forms & $\begin{array}{l}\text { Rates } \\
(\%)\end{array}$ & & $S$ & $\mathrm{R}$ & $\mathrm{S} / \mathrm{R}$ & $S$ & $\mathrm{R}$ & $\mathrm{S} / \mathrm{R}$ & $S$ & $\mathrm{R}$ & $\mathrm{S} / \mathrm{R}$ \\
\hline \multicolumn{12}{|c|}{ B- Flowering stage } \\
\hline \multicolumn{2}{|c|}{ Control } & & 335 & 89.2 & 3.76 & 36.8 & 10.0 & 3.68 & 279 & 90.4 & 3.12 \\
\hline \multicolumn{2}{|l|}{ Mag. } & & 302 & 59.9 & 5.11 & 28.6 & 5.52 & 5.20 & 223 & 55.5 & 4.36 \\
\hline Bas. & 0.07 & $0 \%$ & 306 & 73.1 & 4.18 & 32.2 & 6.34 & 2.10 & 242 & 66.7 & 3.62 \\
\hline \multicolumn{2}{|l|}{ Md. } & & 266 & 42.2 & 6.30 & 27.2 & 2.65 & 10.3 & 181 & 27.9 & 7.68 \\
\hline \multicolumn{2}{|c|}{ FYM (F1) } & & 317 & 571 & 5.55 & 32.2 & 2.52 & 12.8 & 257 & 58.5 & 4.39 \\
\hline \multirow[t]{3}{*}{ Mag } & 0.02 & & 293 & 36.0 & 8.14 & 25.2 & 3.17 & 7.90 & 245 & 32.3 & 7.59 \\
\hline & 0.05 & & 385 & 42.5 & 9.06 & 39.4 & 4.03 & 9.80 & 298 & 28.7 & 10.4 \\
\hline & 0.07 & & 408 & 70.9 & 5.75 & 44.5 & 5.94 & 7.50 & 307 & 64.2 & 4.78 \\
\hline \multirow[t]{3}{*}{ Bas } & 0.02 & & 365 & 58.9 & 6.20 & 39.8 & 10.7 & 3.72 & 269 & 43.9 & 6.13 \\
\hline & 0.05 & $2 \%$ & 448 & 87.5 & 5.12 & 43.2 & 12.6 & 3.43 & 352 & 65.2 & 5.40 \\
\hline & 0.07 & & 502 & 109 & 4.61 & 70.4 & 14.3 & 4.92 & 378 & 76.1 & 4.94 \\
\hline \multirow[t]{3}{*}{$\mathrm{Md}$} & 0.02 & & 409 & 30.7 & 13.3 & 42.1 & 3.68 & 11.4 & 294 & 27.6 & 10.7 \\
\hline & 0.05 & & 376 & 42.7 & 8.81 & 33.4 & 4.08 & 8.20 & 301 & 37.3 & 8.29 \\
\hline & 0.07 & & 491 & 54.8 & 8.96 & 61.1 & 6.06 & 10.1 & 381 & 51.5 & 7.42 \\
\hline \multicolumn{2}{|c|}{ FYM (F2) } & & 443 & 65.9 & 6.72 & 60.4 & 4.20 & 14.4 & 323 & 69.4 & 4.65 \\
\hline \multirow[t]{3}{*}{ Mag } & 0.02 & & 489 & 88.1 & 5.54 & 59.3 & 9.39 & 6.30 & 393 & 70.9 & 5.54 \\
\hline & 0.05 & & 493 & 99.3 & 4.96 & 99.4 & 10.3 & 9.65 & 396 & 83.4 & 4.75 \\
\hline & 0.07 & & 440 & 75.0 & 5.87 & 44.0 & 9.11 & 4.83 & 368 & 68.8 & 5.35 \\
\hline \multirow[t]{3}{*}{ Bas } & 0.02 & & 584 & 89.2 & 6.55 & 92.6 & 11.5 & 8.05 & 467 & 86.2 & 5.42 \\
\hline & 0.05 & $3 \%$ & 684 & 114 & 6.00 & 93.3 & 18.4 & 5.07 & 524 & 101 & 5.14 \\
\hline & 0.07 & & 459 & 78.9 & 5.82 & 58.8 & 10.3 & 5.70 & 398 & 75.8 & 5.25 \\
\hline \multirow[t]{3}{*}{$\mathrm{Md}$} & 0.02 & & 361 & 103 & 3.50 & 46.2 & 10.9 & 4.24 & 283 & 89.7 & 3.15 \\
\hline & 0.05 & & 372 & 107 & 3.48 & 65.3 & 11.4 & 5.73 & 331 & 95.8 & 3.46 \\
\hline & 0.07 & & 322 & 77.8 & 4.14 & 41.8 & 8.09 & 5.17 & 249 & 68.7 & 3.62 \\
\hline \multicolumn{2}{|c|}{ L.S.D. $5 \%$} & & 0.19 & 0.33 & 0.02 & 0.12 & 0.02 & 0.02 & 19.4 & 0.62 & 0.02 \\
\hline
\end{tabular}


(second season) at harvest stage, data presented in Table (6) show that applied Md alone at a rate of $0.07 \%$ favoured $\mathrm{N}$ uptake; such rate of Bas was also superior for $\mathrm{P}$ and $\mathrm{K}$ total contents of straw and grain of wheat. Generally, behavior of nitrogen uptake, regarding effects on wheat yield (straw and grain), followed the same trend of those obtained at vegetative stage; obtained values were significantly higher when mineral fertilizer was applied. Uptake of phosphorus and potassium recorded high values for both straw and grain when FYM $\left(\mathrm{F}_{1}\right)$ was used accompanied with $\mathrm{Md}$ at a rate of $0.07 \%$. The residual effect of these treatments on yield (straw and grain) shows, however, relatively different trend whose values were superior significantly for plants receiving the FYM $\left(\mathrm{F}_{2}\right)$ accompanied with $\mathrm{Md}$. at a rate of $0.05 \%$. Obtained results might be related to decomposition of organic manure, resulting in a possible release for nutrients at the second season especially when FYM $\left(\mathrm{F}_{2}\right)$ was applied.

In fact, El-Maghraby et al (1997) indicated that the long -term farmyard manure application decreased soil $\mathrm{pH}$ and increased humus content which should be reflected on increasing the $\mathrm{N}, \mathrm{P}$ and $\mathrm{K}$ contents either in the straw or in the grains of wheat. Also, Wong et al (1999) found that the dry weight of plant was higher in soil receiving manure compost amendment; increases in dry weight yields indicated a better nutrient status in such compost-amended soil.

It may be worth to mention that high values of $\mathrm{N}, \mathrm{P}$ and $\mathrm{K}$ total contents of wheat and maize plants were recorded when FYM $2 \%\left(\mathrm{~F}_{1}\right)$ was applied in combination with the high studied rate $(0.07$ $\%$ ) of all natural minerals; application of FYM at the rate $3 \%\left(\mathrm{~F}_{2}\right)$ was more effec- tive when used in combination with moderate rate $(0.05 \%)$ of all such minerals.

Concerning the effect of natural mineral forms, obtained data show that FYM $2 \%\left(\mathrm{~F}_{1}\right)$ combined with $0.07 \%$ of $\mathrm{Md}$ was more superior for nutrients uptake by wheat and maize yields; this is also true for FYM 3\% $\left(\mathrm{F}_{2}\right)$ combined with $0.05 \%$ Bas for wheat yield only.

\section{C- Micronutrients uptake by wheat during the studied growth stages}

Table (7) shows data representing the $\mathrm{Fe}, \mathrm{Mn}, \mathrm{Zn}$ and $\mathrm{Cu}$ total contents of shoots and roots along with shoot/root ratios of the studied wheat plants at both vegetative and flowering stages. Data revealed that, at both studied growth stages, values were affected by FYM treatments; FYM $\left(\mathrm{F}_{2}\right)$ was superior as compared to other treatments. Obtained data agree with findings obtained by Wehrheim et al (1999) who reported that high application of sewage sludge raised significantly $\mathrm{Zn}$ concentrations in all plant parts over the whole growing season. Recently, Rupa et al (2003) reported that the effect of added FYM was more evident, on the percentage utilization of $\mathrm{Zn}$ by wheat, in comparison to other treatment combinations.

Concerning of applied natural minerals, alone, at the rate of $0.07 \%$, data show that the Mag, Bas and Md gave the highest values of $\mathrm{Fe}, \mathrm{Mn}, \mathrm{Zn}$ and $\mathrm{Cu}$ uptake, respectively, for both plant parts and shoot/root ratios. This result was not unexpected because the applications of natural minerals were sources of micronutrient elements. Also, results show that values of Fe and $\mathrm{Mn}$ as well as $\mathrm{Zn}$ total content of both shoots and roots, at the two concerned growth stages, increased 
Table 6. Macronutrients total contents of straw and grains (mg/plant) of both studied wheat and maize plants as affected by FYM and natural minerals application.

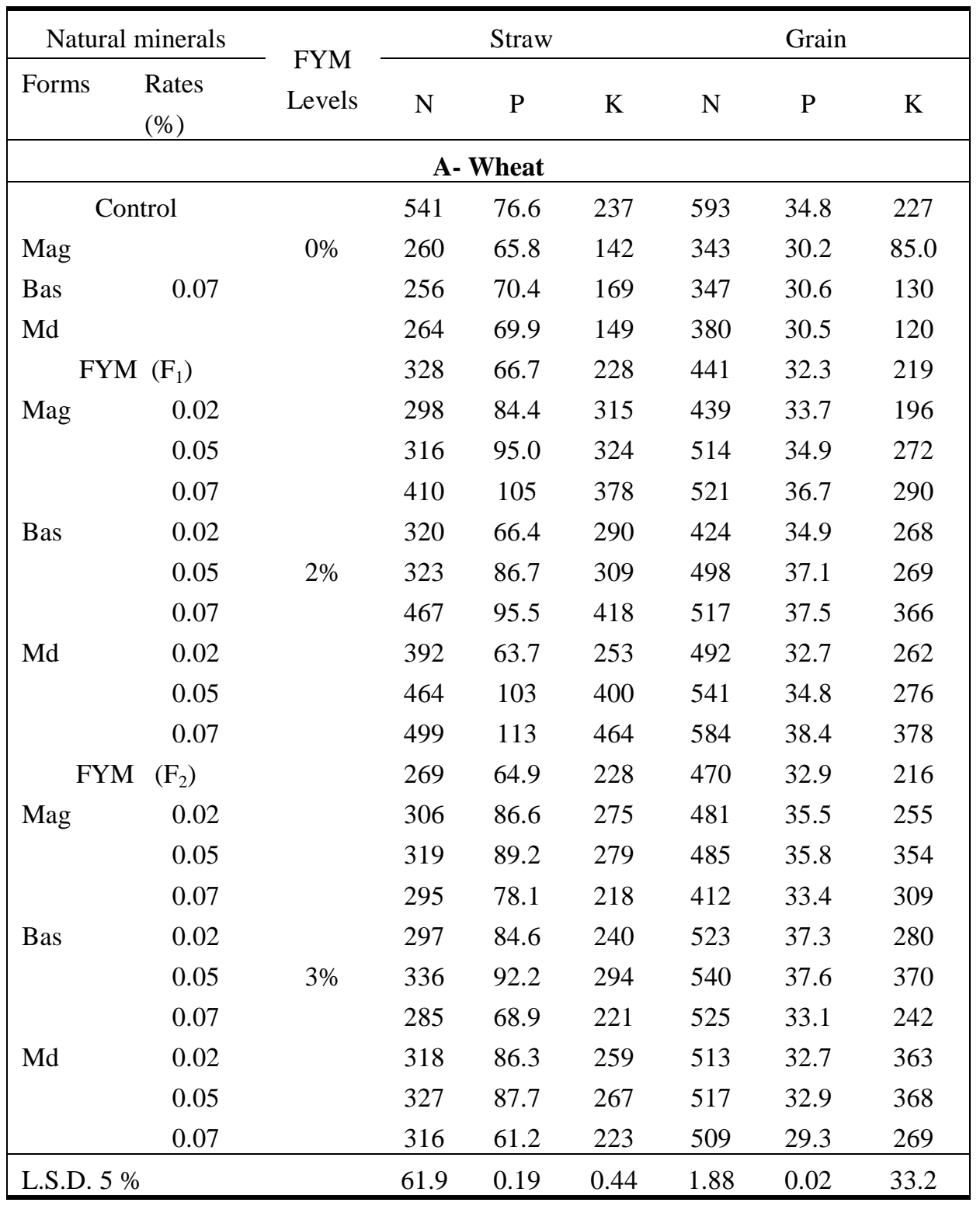


Table 6. Cont.

\begin{tabular}{|c|c|c|c|c|c|c|c|c|}
\hline \multirow{2}{*}{\multicolumn{2}{|c|}{$\begin{array}{l}\text { Natural minerals } \\
\text { Rates }(\%) \\
\text { Forms }\end{array}$}} & \multirow{2}{*}{$\begin{array}{c}\text { FYM } \\
\text { Levels }\end{array}$} & \multicolumn{3}{|c|}{ Straw } & \multicolumn{3}{|c|}{ Grain } \\
\hline & & & $\mathrm{N}$ & $\mathrm{P}$ & $\mathrm{K}$ & $\mathrm{N}$ & $\mathrm{P}$ & $\mathrm{K}$ \\
\hline \multicolumn{9}{|c|}{ B- Maize } \\
\hline \multicolumn{2}{|c|}{ Control } & & 194 & 78.4 & 235 & 329 & 21.9 & 178 \\
\hline Mag & & $0 \%$ & 289 & 62.6 & 286 & 92.0 & 22.5 & 100 \\
\hline Bas & 0.07 & & 244 & 63.0 & 279 & 92.0 & 22.0 & 69 \\
\hline $\mathrm{Md}$ & & & 216 & 78.5 & 240 & 89.0 & 23.0 & 115 \\
\hline \multicolumn{2}{|c|}{$\mathrm{FYM}\left(\mathrm{F}_{1}\right)$} & & 223 & 85.1 & 410 & 227 & 23.1 & 109 \\
\hline \multirow[t]{3}{*}{ Mag } & 0.02 & & 336 & 73.8 & 430 & 290 & 22.4 & 168 \\
\hline & 0.05 & & 339 & 80.9 & 549 & 292 & 22.9 & 179 \\
\hline & 0.07 & & 421 & 88.8 & 601 & 316 & 26.0 & 186 \\
\hline \multirow[t]{3}{*}{ Bas } & 0.02 & & 280 & 73.0 & 432 & 193 & 19.8 & 138 \\
\hline & 0.05 & $2 \%$ & 295 & 76.9 & 395 & 225 & 19.9 & 158 \\
\hline & 0.07 & & 347 & 85.9 & 601 & 322 & 27.5 & 220 \\
\hline \multirow[t]{3}{*}{ Md } & 0.02 & & 385 & 82.9 & 390 & 114 & 14.5 & 115 \\
\hline & 0.05 & & 401 & 89.6 & 404 & 189 & 24.0 & 150 \\
\hline & 0.07 & & 472 & 89.9 & 629 & 335 & 36.7 & 266 \\
\hline \multicolumn{2}{|c|}{$\mathrm{FYM}\left(\mathrm{F}_{2}\right)$} & & 207 & 85.8 & 452 & 252 & 28.9 & 127 \\
\hline \multirow[t]{3}{*}{ Mag } & 0.02 & & 417 & 81.8 & 544 & 350 & 30.4 & 230 \\
\hline & 0.05 & & 426 & 92.5 & 645 & 461 & 35.3 & 242 \\
\hline & 0.07 & & 313 & 73.0 & 489 & 240 & 26.3 & 204 \\
\hline \multirow[t]{3}{*}{ Bas } & 0.02 & & 400 & 91.8 & 487 & 325 & 23.1 & 203 \\
\hline & 0.05 & $3 \%$ & 422 & 95.4 & 575 & 361 & 33.9 & 271 \\
\hline & 0.07 & & 391 & 85.9 & 457 & 208 & 22.8 & 166 \\
\hline \multirow[t]{3}{*}{$\mathrm{Md}$} & 0.02 & & 366 & 83.3 & 526 & 348 & 23.8 & 246 \\
\hline & 0.05 & & 484 & 100 & 645 & 468 & 36.9 & 276 \\
\hline & 0.07 & & 262 & 56.4 & 447 & 310 & 18.6 & 190 \\
\hline \multicolumn{2}{|c|}{ L.S.D. $5 \%$} & & 0.45 & 1.94 & 0.44 & 54.9 & 0.02 & 45.9 \\
\hline
\end{tabular}


Table 7. Micronutrients total contents of both shoots $(\mathrm{S})$ and roots $(\mathrm{R})(\mathrm{mg} / \mathrm{plant})$ along with shoot / root $(\mathrm{S} / \mathrm{R})$ ratios of wheat plants as effected by applied FYM and natural mineral treatments at both vegetative and flowering stages.

\begin{tabular}{|c|c|c|c|c|c|c|c|c|c|c|c|c|c|c|}
\hline \multicolumn{2}{|c|}{ Natural minerals } & \multirow{2}{*}{$\begin{array}{l}\text { FYM } \\
\text { levels }\end{array}$} & \multicolumn{3}{|c|}{$\mathrm{Fe}$} & \multicolumn{3}{|c|}{$\mathrm{Mn}$} & \multicolumn{3}{|c|}{$\mathrm{Zn}$} & \multicolumn{3}{|c|}{$\mathrm{Cu}$} \\
\hline Forms & Rates $(\%)$ & & $\mathrm{S}$ & $\mathrm{R}$ & $\mathrm{S} / \mathrm{R}$ & $S$ & $\mathrm{R}$ & $\mathrm{S} / \mathrm{R}$ & $\mathrm{S}$ & $\mathrm{R}$ & $\mathrm{S} / \mathrm{R}$ & $\mathrm{S}$ & $\mathrm{R}$ & $\mathrm{S} / \mathrm{R}$ \\
\hline \multicolumn{15}{|c|}{ A- Vegetative stage } \\
\hline \multicolumn{2}{|c|}{ Control } & & 3.33 & 0.73 & 3.98 & 0.37 & 0.15 & 2.47 & 0.41 & 0.46 & 0.89 & 0.08 & 0.08 & 1.00 \\
\hline Mag. & & $0 \%$ & 2.49 & 0.97 & 2.57 & 0.36 & 0.06 & 6.00 & 0.21 & 0.03 & 7.00 & 0.09 & 0.04 & 2.25 \\
\hline Bas & 0.07 & & 2.13 & 0.85 & 2.51 & 0.58 & 0.16 & 3.63 & 1.52 & 0.06 & 25.3 & 0.11 & 0.04 & 2.75 \\
\hline \multirow[t]{2}{*}{$\mathrm{Md}$} & & & 1.11 & 0.43 & 2.58 & 0.22 & 0.05 & 4.40 & 0.32 & 0.03 & 10.7 & 0.12 & 0.04 & 3.00 \\
\hline & FYM (F1) & & 3.16 & 0.74 & 4.33 & 0.40 & 0.15 & 2.67 & 0.93 & 0.89 & 1.04 & 0.12 & 0.08 & 1.5 \\
\hline \multirow[t]{3}{*}{ Mag } & 0.02 & & 2.12 & 0.76 & 2.79 & 0.46 & 0.10 & 4.60 & 2.11 & 0.91 & 2.32 & 0.19 & 0.08 & 2.38 \\
\hline & 0.05 & & 2.65 & 0.85 & 3.12 & 0.64 & 0.17 & 3.76 & 2.10 & 1.07 & 1.96 & 0.17 & 0.04 & 4.25 \\
\hline & 0.07 & & 3.19 & 0.98 & 3.26 & 1.09 & 0.17 & 6.41 & 2.32 & 1.09 & 2.13 & 0.20 & 0.09 & 2.22 \\
\hline \multirow[t]{3}{*}{ Bas } & 0.02 & & 2.64 & 0.51 & 5.18 & 0.35 & 0.08 & 4.38 & 1.37 & 1.09 & 1.25 & 0.20 & 0.07 & 2.86 \\
\hline & 0.05 & $2 \%$ & 2.47 & 0.51 & 4.84 & 0.42 & 0.12 & 3.50 & 1.84 & 1.05 & 1.75 & 0.16 & 0.05 & 3.20 \\
\hline & 0.07 & & 3.03 & 0.94 & 3.22 & 0.87 & 0.14 & 6.21 & 2.37 & 1.07 & 2.21 & 0.19 & 0.07 & 2.71 \\
\hline \multirow[t]{3}{*}{ Md } & 0.02 & & 2.24 & 0.83 & 2.69 & 0.76 & 0.24 & 3.17 & 1.53 & 0.91 & 1.68 & 0.16 & 0.08 & 2.00 \\
\hline & 0.05 & & 2.51 & 0.89 & 2.82 & 0.92 & 0.23 & 4.00 & 1.54 & 0.92 & 1.67 & 0.13 & 0.08 & 1.63 \\
\hline & 0.07 & & 2.87 & 0.97 & 2.96 & 1.38 & 0.34 & 4.06 & 2.58 & 0.99 & 2.61 & 0.20 & 0.09 & 2.22 \\
\hline \multicolumn{2}{|c|}{ FYM (F2) } & & 4.34 & 1.09 & 4.50 & 1.15 & 0.17 & 6.76 & 1.41 & 0.88 & 1.60 & 0.12 & 0.08 & 1.50 \\
\hline \multirow[t]{3}{*}{ Mag } & 0.02 & & 3.85 & 1.69 & 2.28 & 0.55 & 0.23 & 2.39 & 1.89 & 0.11 & 17.1 & 0.21 & 0.07 & 3.00 \\
\hline & 0.05 & & 3.97 & 1.77 & 2.24 & 0.89 & 0.20 & 4.45 & 2.27 & 0.16 & 14.2 & 0.13 & 0.08 & 1.63 \\
\hline & 0.07 & & 3.19 & 1.56 & 2.04 & 0.45 & 0.26 & 1.73 & 1.47 & 0.11 & 13.4 & 0.21 & 0.09 & 2.30 \\
\hline \multirow[t]{3}{*}{ Bas } & 0.02 & & 3.28 & 1.08 & 3.04 & 0.72 & 0.22 & 3.27 & 1.58 & 0.84 & 1.88 & 0.21 & 0.08 & 2.63 \\
\hline & 0.05 & $3 \%$ & 3.48 & 1.17 & 2.97 & 0.84 & 0.22 & 3.82 & 2.39 & 0.82 & 2.91 & 0.18 & 0.08 & 2.25 \\
\hline & 0.07 & & 2.56 & 0.83 & 3.08 & 0.61 & 0.16 & 3.81 & 1.29 & 0.52 & 2.48 & 0.26 & 0.11 & 2.36 \\
\hline \multirow[t]{3}{*}{$\mathrm{Md}$} & 0.02 & & 2.91 & 1.06 & 2.75 & 1.39 & 0.42 & 3.31 & 1.85 & 0.13 & 14.2 & 0.13 & 0.08 & 1.63 \\
\hline & 0.05 & & 3.77 & 1.11 & 3.39 & 1.51 & 0.44 & 3.43 & 2.67 & 0.16 & 16.7 & 0.12 & 0.06 & 2.00 \\
\hline & 0.07 & & 3.60 & 1.06 & 3.39 & 0.99 & 0.39 & 2.54 & 1.45 & 0.17 & 8.53 & 0.14 & 0.09 & 1.50 \\
\hline \multicolumn{3}{|c|}{ L.S.D. $5 \%$} & 0.01 & 0.01 & 0.04 & 0.01 & 0.01 & 0.01 & 0.02 & 0.03 & 0.07 & 0.01 & 0.01 & 0.01 \\
\hline
\end{tabular}


Table 7. Cont.

\begin{tabular}{|c|c|c|c|c|c|c|c|c|c|c|c|c|c|c|}
\hline \multicolumn{2}{|c|}{ Natural minerals } & \multirow{2}{*}{$\begin{array}{l}\text { FYM } \\
\text { levels }\end{array}$} & \multicolumn{3}{|c|}{$\mathrm{Fe}$} & \multicolumn{3}{|c|}{$\mathrm{Mn}$} & \multicolumn{3}{|c|}{$\mathrm{Zn}$} & \multicolumn{3}{|c|}{$\mathrm{Cu}$} \\
\hline Forms & Rates (\%) & & $\mathrm{S}$ & $\mathrm{R}$ & $\mathrm{S} / \mathrm{R}$ & $S$ & $\mathrm{R}$ & $\mathrm{S} / \mathrm{R}$ & $\mathrm{S}$ & $\mathrm{R}$ & $\mathrm{S} / \mathrm{R}$ & $\mathrm{S}$ & $\mathrm{R}$ & $\mathrm{S} / \mathrm{R}$ \\
\hline \multicolumn{15}{|c|}{ B- Flowering stage } \\
\hline \multicolumn{2}{|c|}{ Control } & & 17.8 & 2.73 & 6.52 & 0.89 & 0.17 & 5.23 & 0.21 & 0.10 & 2.10 & 0.08 & 0.01 & 8.0 \\
\hline Mag & & & 20.5 & 2.86 & 7.17 & 0.99 & 0.06 & 16.5 & 0.18 & 0.05 & 3.60 & 0.06 & 0.01 & 6.00 \\
\hline Bas & 0.07 & $0 \%$ & 19.1 & 2.60 & 7.36 & 1.52 & 0.15 & 10.1 & 0.10 & 0.03 & 3.30 & 0.05 & 0.02 & 2.50 \\
\hline Md & & & 16.9 & 1.10 & 15.4 & 0.92 & 0.09 & 10.2 & 0.27 & 0.05 & 5.40 & 0.08 & 0.01 & 8.00 \\
\hline \multicolumn{2}{|c|}{ FYM (F1) } & & 13.4 & 2.22 & 6.04 & 0.71 & 0.15 & 4.73 & 0.19 & 0.05 & 3.8 & 0.06 & 0.02 & 3.00 \\
\hline \multirow[t]{3}{*}{ Mag } & 0.02 & & 15.7 & 2.91 & 5.41 & 0.43 & 0.05 & 8.60 & 0.12 & 0.03 & 4.00 & 0.06 & 0.01 & 6.00 \\
\hline & 0.05 & & 24.5 & 4.20 & 5.83 & 0.71 & 0.04 & 17.8 & 0.35 & 0.10 & 3.50 & 0.06 & 0.01 & 6.00 \\
\hline & 0.07 & & 28.7 & 5.76 & 4.98 & 0.85 & 0.08 & 10.6 & 0.81 & 0.16 & 5.06 & 0.07 & 0.01 & 7.00 \\
\hline \multirow[t]{3}{*}{ Bas } & 0.02 & & 13.8 & 1.30 & 10.7 & 0.54 & 0.11 & 4.91 & 0.20 & 0.09 & 2.22 & 0.14 & 0.03 & 4.67 \\
\hline & 0.05 & $2 \%$ & 17.5 & 1.42 & 12.3 & 0.69 & 0.15 & 4.60 & 0.29 & 0.55 & 0.53 & 0.09 & 0.02 & 4.50 \\
\hline & 0.07 & & 27.7 & 2.67 & 10.4 & 0.79 & 0.18 & 4.39 & 0.35 & 0.56 & 0.63 & 0.14 & 0.06 & 2.33 \\
\hline \multirow[t]{3}{*}{ Md } & 0.02 & & 20.6 & 0.90 & 22.9 & 0.92 & 0.28 & 3.29 & 0.28 & 0.02 & 14.0 & 0.07 & 0.01 & 7.00 \\
\hline & 0.05 & & 22.5 & 1.37 & 16.4 & 1.14 & 0.25 & 4.56 & 0.32 & 0.02 & 16.0 & 0.10 & 0.01 & 10.0 \\
\hline & 0.07 & & 22.7 & 2.13 & 10.6 & 1.47 & 0.33 & 4.45 & 0.32 & 0.48 & 0.67 & 0.11 & 0.02 & 5.50 \\
\hline FY & $M(F 2)$ & & 28.8 & 3.02 & 9.53 & 0.93 & 0.17 & 5.47 & 0.35 & 0.05 & 7.00 & 0.12 & 0.02 & 6.00 \\
\hline \multirow[t]{3}{*}{ Mag } & 0.02 & & 33.5 & 8.83 & 3.80 & 1.79 & 0.13 & 13.8 & 0.22 & 0.06 & 3.67 & 0.08 & 0.03 & 2.67 \\
\hline & 0.05 & & 40.6 & 9.16 & 4.43 & 2.30 & 0.19 & 12.1 & 0.77 & 0.48 & 1.60 & 0.07 & 0.04 & 1.75 \\
\hline & 0.07 & & 32.8 & 7.61 & 4.30 & 1.77 & 0.12 & 14.8 & 0.15 & 0.07 & 2.14 & 0.09 & 0.04 & 2.25 \\
\hline \multirow[t]{3}{*}{ Bas } & 0.02 & & 33.4 & 3.30 & 10.1 & 1.70 & 0.17 & 10.0 & 0.66 & 0.15 & 4.40 & 0.09 & 0.07 & 1.30 \\
\hline & 0.05 & $3 \%$ & 34.6 & 7.26 & 4.76 & 2.03 & 0.26 & 7.81 & 0.74 & 0.25 & 2.96 & 0.12 & 0.05 & 2.40 \\
\hline & 0.07 & & 29.2 & 2.87 & 10.2 & 1.60 & 0.14 & 11.4 & 0.56 & 0.08 & 7.00 & 0.14 & 0.08 & 1.75 \\
\hline \multirow[t]{3}{*}{ Md } & 0.02 & & 21.2 & 2.66 & 7.97 & 1.93 & 0.41 & 4.71 & 0.39 & 0.10 & 3.90 & 0.05 & 0.03 & 1.67 \\
\hline & 0.05 & & 33.0 & 2.92 & 11.3 & 2.85 & 0.46 & 6.20 & 0.93 & 0.86 & 1.08 & 0.07 & 0.03 & 2.33 \\
\hline & 0.07 & & 19.9 & 2.21 & 9.00 & 1.71 & 0.23 & 7.43 & 0.35 & 0.07 & 5.00 & 0.08 & 0.03 & 2.67 \\
\hline \multicolumn{2}{|c|}{ L.S.D. $5 \%$} & & 0.42 & 0.23 & 1.03 & 0.23 & 0.01 & 0.25 & 0.01 & 0.01 & 0.45 & 0.01 & 0.01 & 1.00 \\
\hline
\end{tabular}

Arab Univ. J. Agric. Sci., 14(1), 2006 
significantly in both studied plant parts by application of FYM $\left(\mathrm{F}_{2}\right)$ accompanied with moderate rate $(0.05 \%)$ of both magnetite (Mag) and manganese dust (Md); $\mathrm{Cu}$ uptake was significantly favoured for plants receiving FYM $\left(\mathrm{F}_{2}\right)$ combined with the high rate of basic slage (Bas., 0.07\%).

With regard to the rate of natural minerals, the values for micronutrients total contents of shoots, roots along with shoot/root ratios at the two studied growth stages were, generally, high with application of FYM $\left(\mathrm{F}_{1}\right)$ accompanied with the high rate $(0.07 \%)$ of all natural minerals (Mag, Bas and Md) while application of FYM $\left(\mathrm{F}_{2}\right)$ was more favourable with the moderate rate $(0.05 \%)$ of all natural minerals. Relatively different trend was obtained with $\mathrm{Cu}$ uptake whose responses to applied FYM $\left(\mathrm{F}_{2}\right)$ were obtained when accompanied with the high rate of all natural minerals.

\section{D- Micronutrients at harvest stage of wheat-maize system}

Concerning the micronutrients uptake of both wheat (first season) and maize (second season) at harvest stage, data presented in Table (8) show general responses to applied FYM and natural minerals treatments. Application of natural minerals alone at a rate of $0.07 \%$ seemed to be almost similar to those of growth stages of wheat. Furthermore, obtained results revealed that the $\mathrm{Fe}$ and $\mathrm{Mn}$ as well as $\mathrm{Zn}$ total contents of wheat (straw and grains) were significantly higher when FYM $\left(\mathrm{F}_{1}\right)$ was used accompanied with high the rate $(0.07 \%)$ of Mag and $\mathrm{Md}$, respectively, $\mathrm{Cu}$ total content for straw and grains being with no clear trend. Relatively different trend was obtained by maize yield (residual effect); obtained results reveal that superiority was significant when FYM $\left(\mathrm{F}_{2}\right)$ was accompanied with the moderate rate $(0.05 \%)$ of the same natural mineral previously used.

With regard to the effect of natural mineral rates, high and moderate doses of all accompanied with FYM $\left(\mathrm{F}_{1}\right)$ and FYM $\left(\mathrm{F}_{2}\right)$, respectively, gave the highest values of micronutrients uptake during the two studied seasons.

Concerning the effect of natural mineral forms, $\mathrm{Fe}$ and $\mathrm{Mn}$ total contents of in straw and grains of wheat as well as maize were more superior when either of the two rates of FYM accompanied with Mag and Md Were used, respectively. On the other hand, $\mathrm{Zn}$ total content of wheat (straw and grains) was favoured in plants receiving FYM $\left(\mathrm{F}_{1}\right)$ accompanied with Md. but FYM $\left(\mathrm{F}_{2}\right)$ accompanied with Mag was superior, an opposite trend being shown for maize.

Hence, regardless of FYM application, micronutrients uptake for wheat and maize was, generally, superior when $\mathrm{Md}$ was used, Fe uptake being superior when Mag was applied.

\section{CONCLUSIONS}

Application of farmyard manure combined with studied natural minerals (magnetite, basic slag and manganese dust), as sources of micronutrients, increased nutrients availability which was reflected on growth and uptake of nutrients by plants. Generally, the highest yield of wheat (first season) was obtained by using the recommended dose of mineral fertilizers; highest yield of maize (residual effect) was, however, obtained when FYM was applied individually or combined with naturals. However, this 
Table 8. Micronutrients total contents of straw and grains(mg/plant)of both studied wheat and maize plants as affected by FYM and natural minerals application.

\begin{tabular}{|c|c|c|c|c|c|c|c|c|c|c|}
\hline \multicolumn{2}{|c|}{ Natural minerals } & \multirow{2}{*}{$\begin{array}{l}\text { FYM } \\
\text { levels }\end{array}$} & \multicolumn{4}{|c|}{ Straw } & \multicolumn{4}{|c|}{ Grain } \\
\hline Forms & Rates (\%) & & $\mathrm{Fe}$ & Mn & $\mathrm{Zn}$ & $\mathrm{Cu}$ & $\mathrm{Fe}$ & $\mathrm{Mn}$ & $\mathrm{Zn}$ & $\mathrm{Cu}$ \\
\hline \multicolumn{11}{|c|}{ A- Wheat } \\
\hline \multicolumn{2}{|c|}{ Control } & & 11.3 & 1.71 & 123 & 0.01 & 87.5 & 1.73 & 2.60 & 0.02 \\
\hline Mag & & & 8.98 & 1.71 & 1.14 & 0.01 & 104 & 1.63 & 1.95 & 0.02 \\
\hline Bas & 0.07 & $0 \%$ & 6.00 & 1.83 & 1.44 & 0.01 & 70.5 & 1.88 & 1.46 & 0.01 \\
\hline \multirow[t]{2}{*}{$\mathrm{Md}$} & & & 8.84 & 1.72 & 2.25 & 0.01 & 38.1 & 1.68 & 2.26 & 0.02 \\
\hline & $\mathrm{FYM}\left(\mathrm{F}_{1}\right)$ & & 15.9 & 1.99 & 2.93 & 0.02 & 102 & 1.68 & 2.40 & 0.02 \\
\hline \multirow[t]{3}{*}{ Mag } & 0.02 & & 21.7 & 1.82 & 1.82 & 0.01 & 106 & 1.77 & 5.23 & 0.02 \\
\hline & 0.05 & & 27.9 & 1.88 & 2.07 & 0.02 & 139 & 1.77 & 6.27 & 0.02 \\
\hline & 0.07 & & 30.2 & 1.96 & 3.74 & 0.02 & 143 & 2.01 & 6.64 & 0.02 \\
\hline \multirow[t]{3}{*}{ Bas } & 0.02 & & 9.21 & 1.76 & 1.62 & 0.01 & 124 & 1.80 & 1.86 & 0.02 \\
\hline & 0.05 & $2 \%$ & 11.1 & 1.92 & 6.62 & 0.01 & 132 & 1.90 & 3.45 & 0.02 \\
\hline & 0.07 & & 14.9 & 1.93 & 2.35 & 0.02 & 138 & 1.97 & 5.91 & 0.02 \\
\hline \multirow[t]{4}{*}{$\mathrm{Md}$} & 0.02 & & 13.8 & 1.98 & 1.68 & 0.01 & 109 & 2.02 & 1.93 & 0.02 \\
\hline & 0.05 & & 14.3 & 2.02 & 8.42 & 0.02 & 126 & 2.13 & 2.93 & 0.02 \\
\hline & 0.07 & & 17.4 & 2.05 & 8.83 & 0.02 & 137 & 2.29 & 6.95 & 0.02 \\
\hline & $\mathrm{FYM}\left(\mathrm{F}_{2}\right)$ & & 22.1 & 2.01 & 3.21 & 0.03 & 105 & 1.77 & 3.35 & 0.02 \\
\hline \multirow[t]{3}{*}{ Mag } & 0.02 & & 15.2 & 1.75 & 1.02 & 0.01 & 127 & 1.87 & 6.51 & 0.02 \\
\hline & 0.05 & & 18.4 & 1.78 & 1.24 & 0.01 & 128 & 1.97 & 6.76 & 0.02 \\
\hline & 0.07 & & 13.1 & 1.70 & 0.91 & 0.01 & 116 & 1.75 & 5.97 & 0.02 \\
\hline \multirow[t]{3}{*}{ Bas } & 0.02 & & 12.6 & 1.72 & 1.01 & 0.01 & 105 & 1.76 & 5.50 & 0.02 \\
\hline & 0.05 & $3 \%$ & 16.8 & 1.76 & 1.19 & 0.01 & 111 & 1.90 & 6.16 & 0.02 \\
\hline & 0.07 & & 11.7 & 1.75 & 0.83 & 0.01 & 107 & 1.66 & 2.00 & 0.02 \\
\hline \multirow[t]{3}{*}{$\mathrm{Md}$} & 0.02 & & 9.95 & 1.76 & 1.03 & 0.01 & 106 & 2.20 & 1.85 & 0.02 \\
\hline & 0.05 & & 11.5 & 1.82 & 1.12 & 0.01 & 116 & 2.26 & 3.15 & 0.02 \\
\hline & 0.07 & & 9.68 & 1.73 & 0.90 & 0.01 & 84.8 & 2.14 & 1.35 & 0.02 \\
\hline \multicolumn{2}{|c|}{ L.S.D. $5 \%$} & & 1.01 & 0.02 & 0.01 & 0.01 & 0.52 & 0.24 & 0.02 & 0.01 \\
\hline
\end{tabular}


Table 8. Cont.

\begin{tabular}{|c|c|c|c|c|c|c|c|c|c|c|}
\hline \multicolumn{2}{|c|}{ Natural minerals } & \multirow{2}{*}{$\begin{array}{l}\text { FYM } \\
\text { levels }\end{array}$} & \multicolumn{4}{|c|}{ Straw } & \multicolumn{4}{|c|}{ Grain } \\
\hline Forms & Rates $(\%)$ & & $\mathrm{Fe}$ & $\mathrm{Mn}$ & $\mathrm{Zn}$ & $\mathrm{Cu}$ & $\mathrm{Fe}$ & Mn & $\mathrm{Zn}$ & $\mathrm{Cu}$ \\
\hline \multicolumn{11}{|c|}{ B- Maize } \\
\hline \multicolumn{2}{|c|}{ Control } & & 7.66 & 0.30 & 0.36 & 0.02 & 4.98 & 0.09 & 0.15 & 0.01 \\
\hline Mag & & & 12.5 & 0.50 & 0.54 & 0.02 & 4.73 & 0.14 & 0.22 & 0.01 \\
\hline Bas & 0.07 & $0 \%$ & 11.1 & 0.62 & 0.52 & 0.02 & 4.62 & 0.20 & 0.49 & 0.01 \\
\hline Md & & & 9.22 & 0.71 & 0.45 & 0.02 & 4.29 & 0.28 & 0.21 & 0.01 \\
\hline \multicolumn{2}{|c|}{ FYM $\left(\mathrm{F}_{1}\right)$} & & 8.33 & 0.35 & 0.47 & 0.02 & 3.95 & 0.09 & 0.15 & 0.01 \\
\hline \multirow[t]{3}{*}{ Mag } & 0.02 & & 11.9 & 0.82 & 0.47 & 0.02 & 6.38 & 0.16 & 0.25 & 0.01 \\
\hline & 0.05 & & 13.2 & 0.88 & 0.62 & 0.02 & 6.89 & 0.20 & 0.31 & 0.01 \\
\hline & 0.07 & & 18.4 & 0.99 & 0.87 & 0.02 & 7.84 & 0.30 & 0.46 & 0.01 \\
\hline \multirow[t]{3}{*}{ Bas } & 0.02 & & 9.34 & 0.49 & 0.50 & 0.02 & 4.72 & 0.13 & 0.24 & 0.01 \\
\hline & 0.05 & $2 \%$ & 9.73 & 0.51 & 0.51 & 0.02 & 5.13 & 0.14 & 0.26 & 0.01 \\
\hline & 0.07 & & 11.6 & 1.08 & 0.56 & 0.02 & 8.04 & 0.24 & 0.37 & 0.01 \\
\hline \multirow[t]{3}{*}{ Md } & 0.02 & & 11.5 & 0.46 & 0.40 & 0.02 & 3.88 & 0.23 & 0.19 & 0.01 \\
\hline & 0.05 & & 13.2 & 0.87 & 0.55 & 0.02 & 4.63 & 0.30 & 0.19 & 0.01 \\
\hline & 0.07 & & 15.4 & 1.21 & 0.69 & 0.02 & 6.67 & 0.37 & 0.34 & 0.01 \\
\hline \multicolumn{2}{|c|}{$\mathrm{FYM}\left(\mathrm{F}_{2}\right)$} & & 12.9 & 0.73 & 0.49 & 0.02 & 6.11 & 0.13 & 0.29 & 0.01 \\
\hline \multirow[t]{3}{*}{ Mag } & 0.02 & & 15.5 & 0.76 & 0.58 & 0.03 & 6.03 & 0.16 & 0.26 & 0.01 \\
\hline & 0.05 & & 19.9 & 1.03 & 0.72 & 0.02 & 15.2 & 0.16 & 0.29 & 0.01 \\
\hline & 0.07 & & 13.0 & 0.71 & 0.57 & 0.02 & 8.50 & 0.13 & 0.23 & 0.01 \\
\hline \multirow[t]{3}{*}{ Bas } & 0.02 & & 10.5 & 1.14 & 0.67 & 0.02 & 6.44 & 0.22 & 0.36 & 0.01 \\
\hline & 0.05 & $3 \%$ & 10.9 & 1.37 & 0.73 & 0.02 & 10.1 & 0.24 & 0.78 & 0.01 \\
\hline & 0.07 & & 9.68 & 0.77 & 0.43 & 0.02 & 5.23 & 0.19 & 0.31 & 0.01 \\
\hline \multirow[t]{3}{*}{ Md } & 0.02 & & 14.8 & 1.29 & 0.91 & 0.02 & 9.91 & 0.51 & 0.54 & 0.01 \\
\hline & 0.05 & & 15.7 & 1.68 & 0.91 & 0.03 & 10.6 & 0.54 & 0.80 & 0.01 \\
\hline & 0.07 & & 11.6 & 0.94 & 0.47 & 0.02 & 5.82 & 0.33 & 0.47 & 0.01 \\
\hline \multicolumn{2}{|c|}{ L.S.D. $5 \%$} & & 1.12 & 0.21 & 0.23 & 0.01 & 0.23 & 0.03 & 0.05 & 0.01 \\
\hline
\end{tabular}


study needs to be confirmed by increasing searching work on other natural minerals, which are different in their content of micronutrients; suitable crops have to be established.

\section{ACKNOWLEDGMENT}

The authors wish to express their sincere gratitude and appreciation to Prof. Dr. Ahmed S. Ahmed for his assistance and cooperation as well as introducing all facilities needed for accomplishing this study.

\section{REFERENCES}

Ayaga, G.; A. Todd and P.C. Brookes (2006). Enhanced biological cycling of phosphorus increases its availability to crops in low-input sub-Saharan farming systems. Soil Biology and Biochemistry, 38: 81-90.

Barssom, W. Sanaa (1998). Comparative effects of inoculation with VA mycorhizal fungi and organic matter addition on phosphorus and micronutrients uptake by maize. Egypt J. Soil Sci., 38: 21- 32.

Basyouny,E.A. (2001). Plant Response of Fertilization in Relation to Micronutrients Status in Plant and Soil. pp. 5558. Ph.D. Thesis, Fac.of Agric., Ain Shams Univ., Cairo, Egypt.

Black, C.A. (1982). Methods of Soil Analysis. pp. 595-616. Amer. Soc. of Agron. Madison, Wisconsin, U.S.A.

Chapman, D. H. and P. E. Pratt (1961). Methods of Analysis for Soils, Plants and Waters. pp. 172-178. Univ. of Calif., Div. Agric. Sci., U.S.A.

El-Maghraby, S.E.; F.A. Hashem and M.M. Wassif (1997). Profitability of using elemental sulphur after two years of application and its relation to organic manure under saline irrigation water. Egypt. J. Soil Sci., 37: 511- 524.

Heluf, G. (2002). Progress research report (2000/2001) of the soil and water management research program, Alemaya research center, Alemaya University. Seventh Eastern and Southern Africa Regional maize Conference, $11^{\text {th }}-15^{\text {th }}$ February, pp. 387-393.

Negm, M.A.; R.G.Kerlous; L.A. Hussen and A.H. El-sayed (2002). Effect of farmyard manure and potassium sulphate application on maize in a calcareous soil. Egypt. J. Soil Sci., 42: 435- 447.

Palm, C.A.; R.J.K. Myers and S.M. Nandwa (1997). Combined use of organic and inorganic nutrient sources for soil fertility maintenance and replenishment. In Replenishing soil fertility in Africa: Buresh, R.J., Sanchez, P.A. and Calhoun, E., Eds.; Soil Sci. Soc. Amer. Sp. Publ. No.51: 193-217. Madison, WI., U.S.A. Rupa, T.R.; Ch.S. Rao; A.S. Rao and M. Singh (2003). Effects of farmyard manure and phosphorus on zinc transformations and phyto-availability in two alfisols of India. Bioresource Technology. 87: 279-288.

Salib, Madlain, M.; R.N. Zaki and M.A. Negm (2002). A comparative study on the significance of applied farmyard manure and other affording materials for barley grown on a saline soil. Zagazig $\mathbf{J}$. Agric. Res. 29: 1185-1198.

Snedecor, G.W. and W.G. Cochran (1980). Statistical Methods. $7^{\text {th }}$ Edition. Iowa State Univ. Press., Ames., IA., U.S.A.

Tolessa, D. and D.K. Friesen (2001). Effect of enriching farmyard manure with mineral fertilizer on grain yield of maize at Bako, western Ethiopia. Seventh Eastern and Southern Africa Regional Maize 
Conference. pp. 335-337. $11^{\text {th }}-15^{\text {th }}$ February.

Wehrheim-Jarausch, B.; B. Mocquot and M. Mench (1999). Absorption and translocation of sludge-borne zinc in field-grown maize (Zea mays L.). European J. Agronomy. 11: 23-33.

Wong, J.W.C.; K.K. Ma; K.M. Fang and C. Cheung (1999). Utilization of a manure compost for organic farming in Hong Kong. Bioresource Technology. 67: 43-46.
Yang, C.; L. Yang; Y. Yang and Z. Ouyang (2004). Rice root growth and nutrient uptake as influenced by organic manure in continuously and alternately flooded paddy soils. Agricultural Water Management. 70: 67-81.

Zaharieva, T. and J. Abadia (1998). Iron-manganese interactions in peanut plants as influenced by the source of applied iron. Iron nutrition in soils and plants. Developments in Plants and Soil Sciences. 59:200-221.

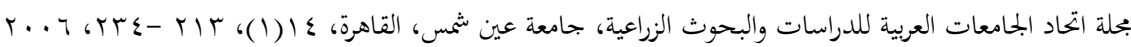

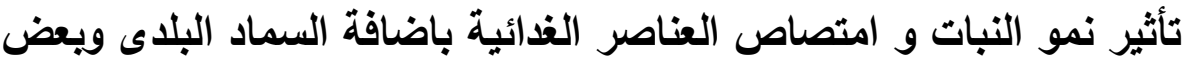
المعادن الطبيعية للآراضى الرملية

$[1 \varepsilon]$

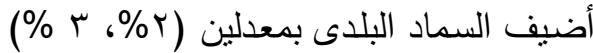

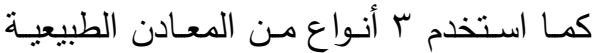

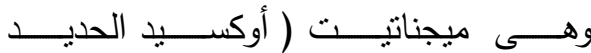
المغناطيسى) وخبث المعادن وتراب المنجنيز

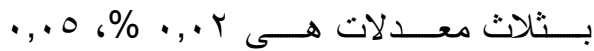

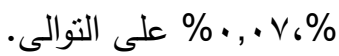
أوضحت النتائج المتحصل علئ عليها لمرحلة

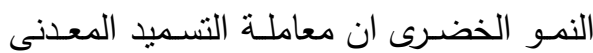

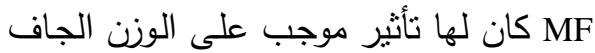

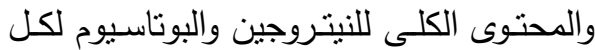

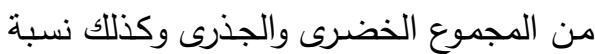

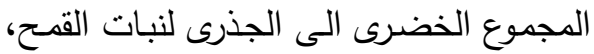

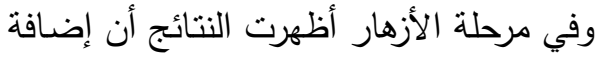

أجريت تجربتين حقليتين على نبات القـح

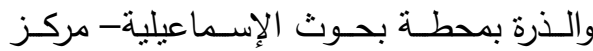

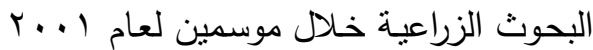

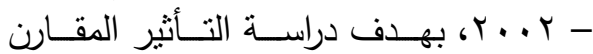

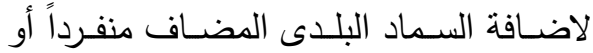

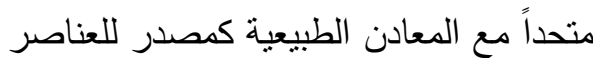
الصغرى أثثاء مراحل نمو القمح (مرحلة النمو كوري

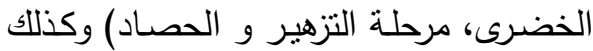

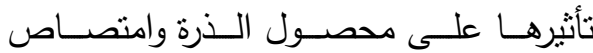

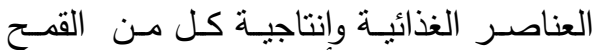
والذرة.

وقد صممت التجربـة في قطاعات كاملة

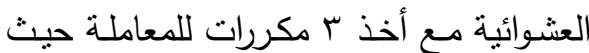




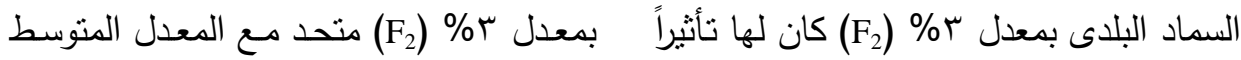

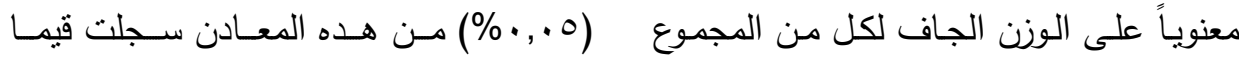

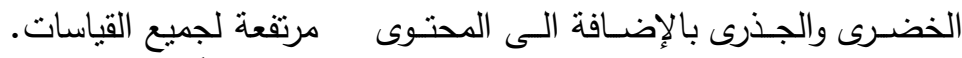

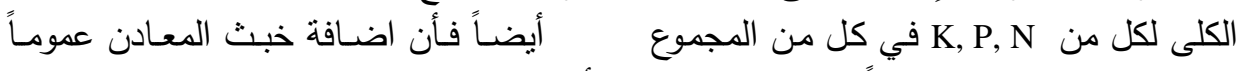

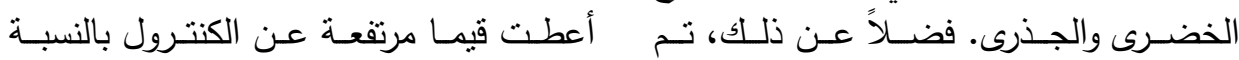

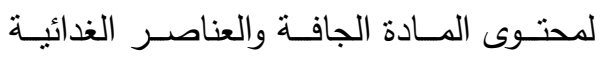

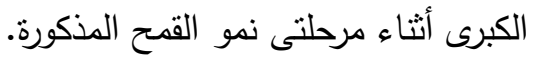

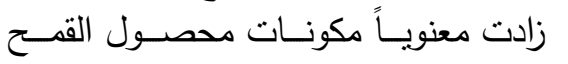

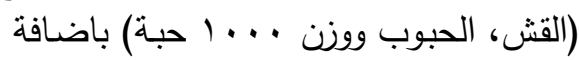

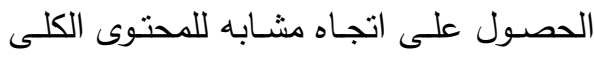

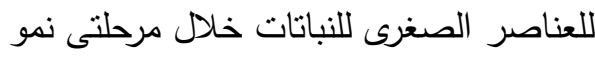

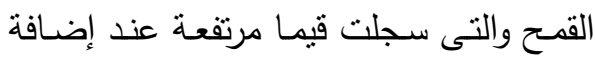

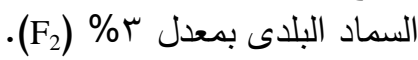

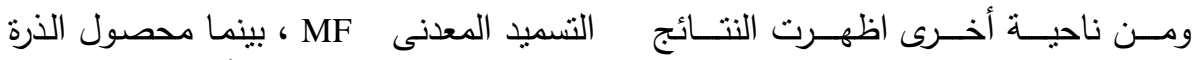

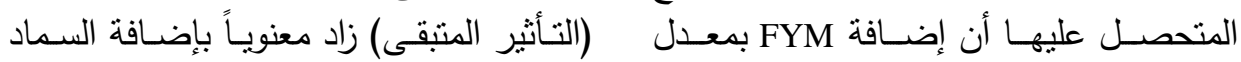

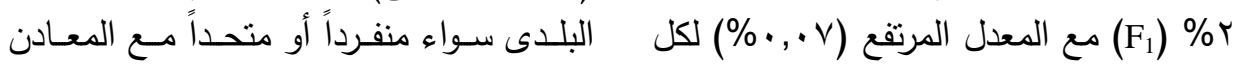

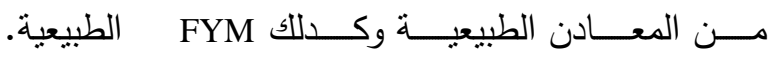
ا أد سمير محمد عبد العزيز 